\title{
RESPONSE OF DEEP-SEA BENTHIC FORAMINIFERA TO A SIMULATED SEDIMENTATION EVENT
}

\author{
P. Linke, ${ }^{1}$ A. V. Altenbach, ${ }^{3}$ G. Graf, ${ }^{1}$ and T. HeEger ${ }^{2}$
}

\begin{abstract}
The response of deep-sea benthic foraminifera to a simulated sedimentation event was assessed in a shipboard microcosm by using transmission electron microscopy, organic carbon, adenosine nucleotide, ETS assays and live observations. A rapid activation of foraminiferal metabolism was detected with an increase in ETS activity and a distinct decrease in AMP to build up ATP. Based on this physiological-awakening reaction, food was gathered by pseudopodial activity and ingested in high quantities. Three days after feeding, high quality food was found in the digestion vacuoles leading to an increase of $89 \%$ in individual organic carbon contents. During the following six days, this food was converted into biomass as lipids and other reserve compounds were built up. After ten days, digestion vacuoles contained degraded matter only. The final shift in individual biomass was $16.9 \%$ in comparison to the initial population.
\end{abstract}

\section{INTRODUCTION}

Recent studies have shown that the deep-sea benthic communities in boreal and arctic oceans are episodically supplied with pulses of organic material via seasonal sedimentation (e.g., Billett and others, 1983; Rice and others, 1986; Tyler, 1988; Thiel and others, 1988/89; Smith and others, 1994; Graf and others, 1995). Research on organic fluxes and the benthic response has shown that a major part of the annual turnover may occur over time spans of only days or weeks (Graf, 1989; Pfannkuche, 1993). Although information on the degradation of organic material in deep-sea sediments (e.g., Rowe and Pariente, 1992) as well as the organisms involved (Gooday, 1988; Gooday and Lambshead, 1989; Gooday and Turley, 1990; Turley and Lochte, 1990; Köster and others, 1991; Altenbach, 1992; Campos-Creasey, 1994) has considerably increased, our knowledge of the deep-sea benthic ecosystem is still in its infancy. It can be expected that deep-sea animals have developed special adaptations to this environment, which is characterized by large fluctuations in food supply (Graf and Linke, 1992; Linke, 1992; Turley and others, 1993).

To investigate this, we conducted a feeding experiment using sediment cores from a known station on the Vøring Plateau (Norwegian Sea) in 1,244 m water depth. With the feeding of plankton material we simulated a sedimentation event in late summer, which is the time when these events occur in nature (Bathmann and others, 1991). The reaction of the benthos was monitored in a synchronized time sched-

'GEOMAR, Forschungszentrum für marine Geowissenschaften, Wischhofstr. 1-3, D-24148 Kiel, Germany.

${ }^{2}$ Institut für Meereskunde, Düsternbrooker Weg 20, D-24105 Kiel, Germany.

${ }^{3}$ Institut für Paläontologie und historische Geologie, Richard Wagner Str. 10, D-80333 München, Germany. ule on the level of the sediment community, the prokaryotes (Köster and others, 1991; Meyer-Reil and Köster, 1992) and the foraminifera (Altenbach, 1992; Graf and Linke, 1992). In the present paper we combine these former results and other physiological measurements with ultrastructural and live observations to assess the foraminiferal reaction with different approaches and show the time scales over which and in what proportion benthic foraminifera were involved in the benthic response to a simulated food pulse.

\section{MATERIAL AND METHODS}

More than 90 sediment cores were collected from one station (Sta. M468; mean water depth 1,244 $\pm 7 \mathrm{~m}$; mean coordinates $67^{\circ} 44.0^{\prime} \mathrm{N}, 05^{\circ} 55.0^{\prime} \mathrm{E}$ ) located on the Vøring Plateau (Norwegian Sea) using a multiple corer (modified from Barnett and others, 1984) during cruise 7/4 of RV "Meteor" on August 19th, 1988 (cruise report in: Hirschleber and others, 1988). Ships drift during the 12 multiple corer hauls was below $1.5 \mathrm{~nm}$ (SD latitude 0.08 ', longitude $\left.0.1^{\prime}\right)$. During the feeding experiment, the same site was sampled again on August 30th (Sta. M533; 1,243 m; $\left.67^{\circ} 44.0^{\prime} \mathrm{N}, 05^{\circ} 55.6^{\prime} \mathrm{E}\right)$ to get control values aboard the ship from in situ conditions. The top and bottom of each core tube were stoppered with 'Delrin' and the sediment cores were kept in a temperature controlled refrigerator under in situ temperature $\left(-0.5^{\circ} \mathrm{C}\right)$.

\section{FEEDING OF SAMPLES}

Natural planktonic and detrital matter sampled from a water depth of $150 \mathrm{~m}$ was concentrated through a $20 \mu \mathrm{m}$ plankton net. The material was suspended in surface water, boiled for 30 minutes, homogenized with a teflon pestle and enriched by centrifugation three times (10 min.; 1,200 rpm; $0^{\circ} \mathrm{C}$ ). Part of the material was frozen until analyses of particulate organic carbon and nitrogen using a Perkin-Elmer CHN Analyzer.

The material added in the experiment had a $\mathrm{C} / \mathrm{N}$ ratio $(<6)$ which indicates a high nutritional value for the deepsea benthic community. For comparison, such low ratios were found in shallow waters during the sedimentation of a spring phytoplankton bloom (Graf and others, 1982). ATP and DNA assays were performed to confirm that this treatment destroyed all the ATP and DNA in the planktonic material. After equilibration to ship-board conditions for 4 days, 5-mL aliquots of the natural "aged" organic material were carefully pipetted into the overlying water of the sediment cores (surface area $78.5 \mathrm{~cm}^{2}$ ). Whereas half the cores received the enrichment, the other half remained untreated serving as unfed controls. The simulated food pulse was 200 $\mathrm{mg}$ of dry weight per core, equivalent to $1.1 \mathrm{~g}$ org. $\mathrm{C} \mathrm{m}$. This corresponds to $1 / 3$ of the annual vertical sedimentation in this area (Bathmann and others, 1990, 1991). The sediment cores were processed in a synchronized time schedule, 
providing a stepwise determination of processes and budget for the timespan of the microcosm experiment. At each sampling date one of 5 sediment cores was used for each method described below.

\section{SEDIMENT DNA ASSAY}

For DNA analysis of the benthic community 5 times 1 $\mathrm{cm}^{3}$ from the upper centimeter of each sediment core (1 of 5 per sampling date) was diluted with $2 \mathrm{~mL}$ ice-cold phosphate buffer $(0.1 \mathrm{M} ; \mathrm{pH}=7.0)$ and mortared for 2 minutes. The homogenate was centrifuged for 10 minutes $(3,500$ $\mathrm{rpm} ; 0^{\circ} \mathrm{C}$ ) after which $0.5 \mathrm{~mL}$ of the supernatant was analyzed for DNA using the DAPI method as described by Kapuscinski and Skozylast (1977). To 3 additional replicates, $100 \mu \mathrm{L}$ of 0.1 to $1 \mu \mathrm{g}$ calf thymus DNA was added as an internal standard in order to correct for adsorption losses in the sediment and for enzymatical decomposition during the extraction procedure.

\section{ISOLATION OF FORAMINIFERA}

The upper centimeter of each sediment core ( 4 of 5 per sampling date) was removed and gently washed in the cold room with precooled seawater on a plastic sieve with a mesh size of $250 \mu \mathrm{m}$. The remains in the sieve were transferred into glass petri-dishes and living foraminifera were picked out with forceps and pasteur pipettes under a dissection microscope. The foraminifera were gently cleaned of adhering detritus. Samples were kept at in situ temperature by means of a cooling device built on the microscope table (Linke, 1989).

\section{FiXATION FOR TRANSMISSION ELECTRON MICROSCOPY (TEM)}

As inorganic compounds reduce the quality of the ultrathin sections, TEM investigations were only conducted in calcareous species like Pyrgo rotalaria, Miliolinella subrotunda and Quinqueloculina seminula. The foraminifera were fixed in seawater buffered with $2.5 \%$ glutaraldehyde and postfixed in $1 \%$ osmium tetroxide. They were decalcified with $0.2 \mathrm{M}$ EDTA (ethylene dinitrile tetraacetate), dehydrated in a graded alcohol series and embedded in ERL resin (10 g vinylcyclohexene, $6 \mathrm{~g}$ DER softening agent, 26 $\mathrm{g}$ nonenylen succinic anhydride, $0.4 \mathrm{~g}$ dimethyl amino ethanol). The sections were cut with a diamond knife and stained with $1 \%$ uranyl acetate and $0.5 \%$ lead citrate. TEM micrographs were taken with a ZEISS 109 operated at $80 \mathrm{KV}$ (details in Heeger, 1990).

\section{CHEMICAL ASSAYS}

For the biochemical assays (organic carbon, adenosine nucleotides, electron transport system) the agglutinated species Cribrostomoides subglobosum was used.

\section{Organic Carbon Assay and Biomass Calculations}

Live specimens of Cribrostomoides subglobosum were picked from the sediment and lyphophilized. Sediment sections of one $\mathrm{cm}$ thickness were taken downcore and stained with Rose Bengal for the determination of abundances of foraminiferal species. The maximum test diameter of individuals was measured with a Wild M8 microscope, and biomass was detected by infrared analysis of wet oxidated individual organic carbon content (Altenbach, 1987). Bulk measurements of up to five specimens in each size class were used for small individuals. Between 34 to 46 individuals were used to establish the allometric function of maximum test size versus organic carbon content for every core. Integrated biomass of the size fraction 400-1,200 $\mu \mathrm{m}$ was used for comparison of samples from different cores. A detailed description of handling, equipment and functional relations is given by Altenbach $(1987,1992)$.

\section{Adenosine Nucleotide (ATP, ADP, AMP) Assays}

The nucleotides ATP, ADP and AMP occupy a central position within the intracellular metabolism of all living organisms since they are the energy carrier between energy-generating processes (such as respiration and decomposition of organic molecules) and energy-consuming processes (e.g., biosynthesis, active transport and movement).

The most common energy carrier for metabolic processes, ATP, has a rapid turnover in the cells and is in equilibrium with its phosphorylase products ADP and AMP. Thus, the ratio at which the nucleotides are found in living cells reflects the energetic state and metabolic activity of the organisms. Adenosine nucleotides of single foraminifera ( 7 to 20 individuals per sampling date) were extracted in boiling TRIS $(0.02 \mathrm{M}$; pH 7.8) buffer (details in Linke, 1992). The tests of the foraminifera were crushed with a glass rod to optimize the extraction efficiency and to shorten the extraction time to $30 \mathrm{sec}-$ onds. All nucleotide extracts were stored deep frozen until analysis. ATP was analyzed with the luciferine-luciferase enzyme system using a JRB ATP-photometer. The nucleotides ADP and AMP were measured after conversion to ATP according to the method of Witzel (1979).

SEM, light and TEM micrographs of fed benthic foraminifera. 1. SEM micrograph of Miliolinella subrotunda. This epibenthic species accumulated detrital material around its aperture a few hours after feeding. Scale bar $=40 \mu \mathrm{m}$. 2. Light micrograph of Cribrostomoides subglobosum with a large food particle at its aperture. Scale bar $=200 \mu \mathrm{m}$. 3-5. TEM micrographs of Miliolinella subrotunda. 3. Cytoplasm containing freshly ingested phytoplankton cells (arrows) three days after feeding. Scale bar $=2 \mu \mathrm{m}$. 4. Three days after feeding, the food vacuoles contained copepod muscle tissue. Scale bar $=2 \mu \mathrm{m}$. 5. Ten days after feeding, stercomata and lithosomes were found in younger chambers of the foraminifera. Scale bar = $0.5 \mu \mathrm{m}$. 6. TEM micrograph of Pyrgo rotalaria showing numerous lipid vesicles (arrows). Scale bar $=2 \mu \mathrm{m}$. 

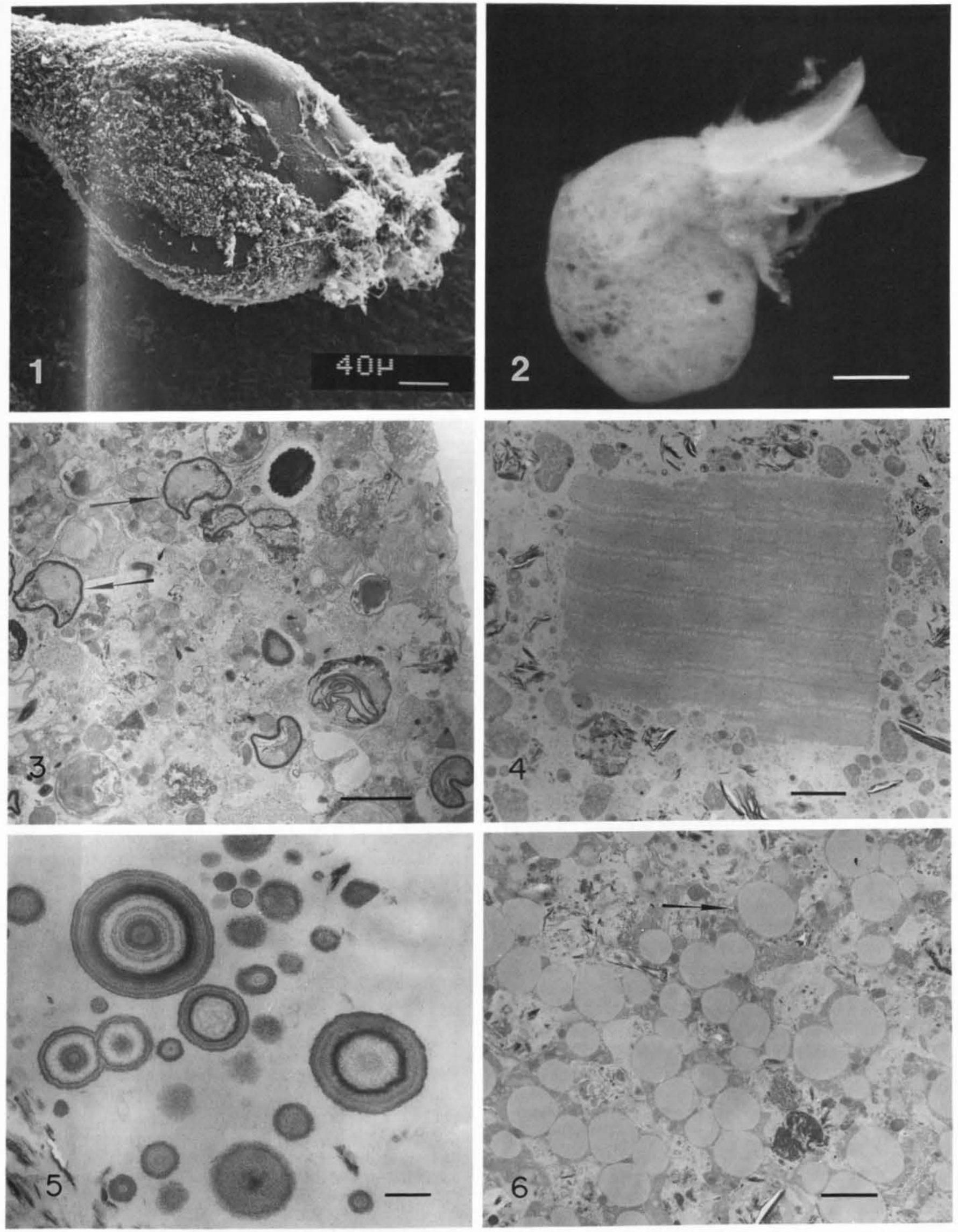


\section{Electron Transport System (ETS) Assay}

This method determines the potential activity of the electron transport system by reducing a dye instead of oxygen or other electron acceptors in extracted respiration chains. ETS activity of 10 to 20 foraminifera was measured in cold phosphate $(0.1 \mathrm{M}$; pH 8.2$)$ buffer (details in Linke, 1992). The number of replicate measurements varied ( 1 to 4 ) due to the varying number of living foraminifera found in the sediment cores. The samples were incubated at a constant temperature in a water bath. Incubation temperatures varied between $18.5^{\circ} \mathrm{C}$ and $22^{\circ} \mathrm{C}$; the samples were correspondingly incubated between 60 and 10 minutes. The reaction was stopped with $1 \mathrm{~mL}$ of $1.0 \mathrm{M} \mathrm{H}_{3} \mathrm{PO}_{4}$ in $4 \%$ formaldehyde solution. After centrifugation for 10 minutes at $3,500 \mathrm{rpm}$, sample absorbance was measured at $492 \mathrm{~nm}$. As controls, to determine nonenzymatic reduction of the tetrazolium dye (INT), $1 \mathrm{~mL}$ of each sample was initially treated with the stopper solution and incubated like the experimental sample. Another control to check the different buffers was carried out by incubating $1 \mathrm{~mL}$ of homogenization buffer in place of the homogenate. The corrected ETS activity values were calculated with the $\mathrm{Ar}$ rhenius formula to the in situ temperature and converted to potential oxygen consumption.

\section{RESULTS AND DISCUSSION}

On the Vøring Plateau in the Norwegian Sea, the pelagic realm is represented in the summer by a nutrient-depleted surface layer, a low phytoplankton biomass with relatively high primary production, and a change in the "grazer"-population from calanoid copepods to pteropods (Bathmann and others, 1990). From sediment trap moorings, each deployed for one year in 1987 and 1988 on the Vøring Plateau, the time between July and September was recognized as the season of the maximum in vertical particle flux. From this knowledge, the working hypothesis was developed that the change from copepods to pteropods as dominant grazers in the euphotic zone could be one trigger for the late summer sedimentation maximum (Bathmann and others, 1990, 1991).

The aim of the feeding experiment was to simulate such a late summer sedimentation event under controlled conditions with sediment cores from a well-known station. During the feeding experiment, the same site on the Vøring Plateau (Sta. M468), where the sediment cores for the experiment had been taken, was sampled again (Sta. M533) to get control values aboard the ship from in situ conditions. At this time, the pelagic sedimentation event happened, which was simulated on board the RV "Meteor." In drifting sediment traps, the natural breakdown of the pelagic summer population by pteropod grazing was monitored (Bathmann and others, 1991), but it had not yet reached the seafloor by our sampling date.

The experimental feeding of sediment cores with enriched plankton material on board the ship led to a marked, but time-limited reaction of all investigated foraminifers. The reaction was monitored with live observations, cytological characteristics and biochemical measurements.

\section{Live and Cytological Observations}

Live observations and TEM investigations revealed that all foraminiferal species investigated in this study reacted to the simulated food pulse. Within one day after feeding, the epibenthic foraminifer Miliolinella subrotunda produced a pronounced plug of accumulated detrital matter, built by pseudopodial activity around the apertural region (Pl. 1, fig. 1). The same species from the unfed sediment cores showed a less distinct plug constituted of resuspended detritus and degraded material only. Fresh food particles were absent. Apart from this activity in front of the aperture, the cytoplasm of the unfed foraminifera was characterized by very old egestion vacuoles and only a limited number if lipid vesicles. There was no ultrastructural difference discernable between unfed foraminifera and those taken from the ir natural habitat on the same sampling day.

On the third day after feeding, the cytoplasm of M.subrotunda showed large, fresh-food vacuoles containing detrital matter with high nutritional value. Fresh phytoplankton cells and copepod muscle tissue were identified in the young chambers (Pl. 1, figs. 3 and 4). After 6 days, nearly all the cytoplasm was filled with vacuoles containing material in various stages of digestion. The material conversion of the food offered was completed within 10 days. Approximately half of the old chambers stored mainly lipid vesicles as reserve substances. Undigestible algal cell walls, copepod remains and stercomata were concentrated in the young chambers, presumably for egestion.

The sediment-surface scavenging Cribrostomoides subglobosum, the versatile and ubiquitous Pyrgo rotalaria and Quinqueloculina seminula (sensu Linke and Lutze, 1993) reacted to the food input with a time delay of 1 to 3 days compared to the facultative suspension feeding Miliolinella subrotunda. Even large particles in relation to the size of the foraminifera can be withdrawn to the apertural region (Pl. 1, fig. 2). The contents of the digestive vacuoles were comparable to those of $M$. subrotunda. Bacteria were not found in the cytoplasm or in digestion vacuoles. Soon after food uptake, the number of lipid vesicles (reserve substances, see Pl. 1, fig. 6) increased substantially compared to the unfed controls and the foraminifera investigated on the first day after feeding. The undigestible remains were concentrated in stercomata. As a final stage of digestion the development of crystals (lithosomes) in the cytoplasm of $P$. rotalaria and $M$. subrotunda was observed ten days after feeding (Pl. 1, fig. 5). These lithosomes are typical endproducts in the digestion of food containing mainly copepods (Hausmann, 1985).

\section{Biochemical Measurements}

The biochemical assays conducted with the sediment surface scavenging Cribrostomoides subglobosum also revealed the reaction of the benthic foraminifera to the simulated food pulse. Only one day after feeding, a distinct increase in ETS activity was observed, indicating a rapid activation of the enzymes of the electron transport chain. Figure 1A depicts the potential oxygen consumption of $C$. subglobosum during the experiment. Only one day after feeding, both fed and unfed foraminifera showed a distinct increase in ETS activity, but both these levels dropped on 

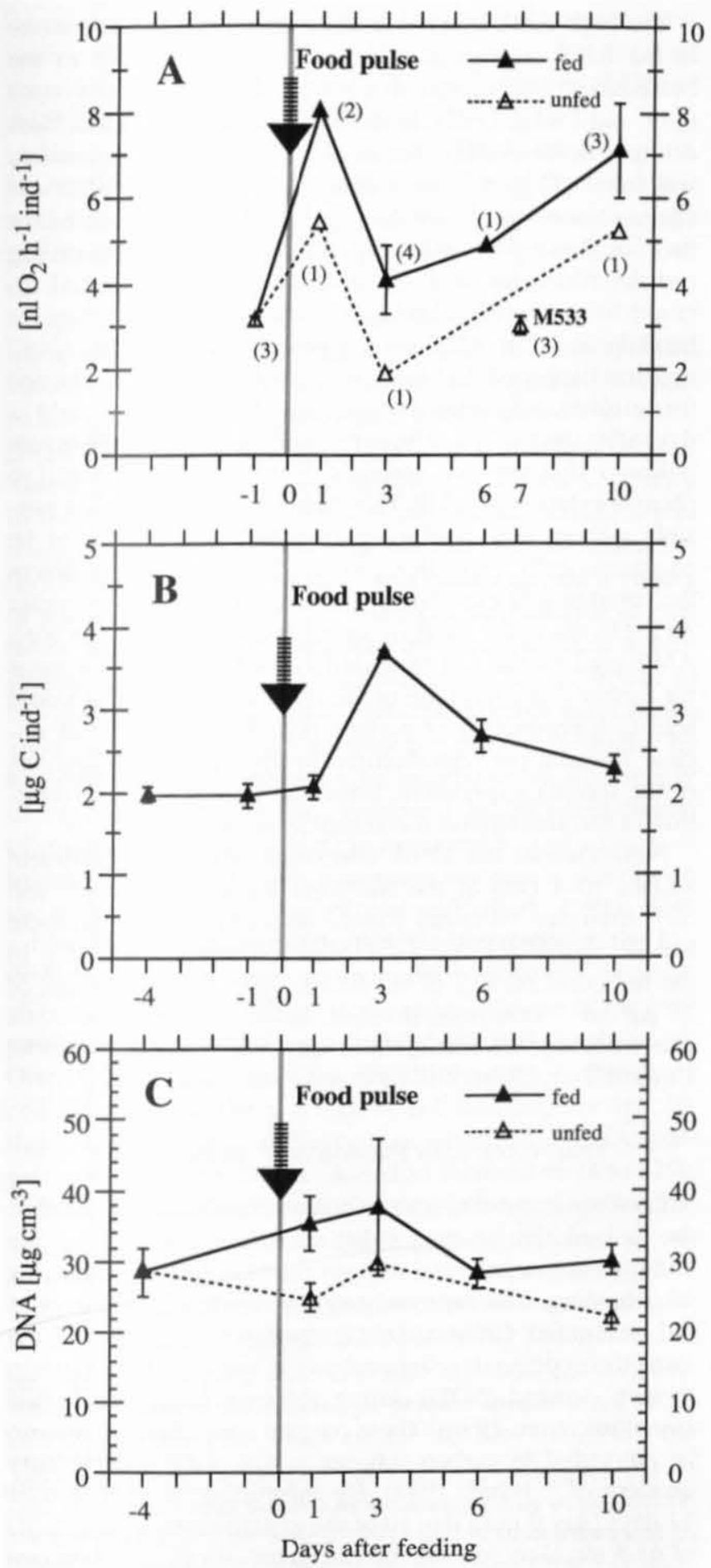

FIGURE 1. A. Development of potential oxygen consumption of fed and unfed Cribrostomoides subglobosum derived from ETS activity measurements. During the feeding experiment, the same site where the sediment cores for the experiment had been taken, was sampled again (Sta. M533) to get ETS control values under natural conditions. The values in brackets indicate the number of replicate measurements (13 to 20 individuals per assay) and the bars the standard deviation, when sufficient living foraminifera for replicate analyses were found. B. Response of $C$. subglobosum to the food pulse derived from the integrated mean bodymass in the size fraction 400 to $1,200 \mu \mathrm{m}$. Thirtyfour to forty-six specimens were measured per core; bars indicate the standard deviation from the specific allometric function of each sample. C. DNA concentration of the sediment surface layer $(0-1 \mathrm{~cm})$ during the experiment $(\mathrm{n}=5)$. The day of transfer from the deep sea to the the third day. Though both curves were almost parallel, the potential oxygen consumption of fed $C$. subglobosum maintained a significantly higher level than that of the unfed individuals. The potential oxygen consumption of foraminifera selected from the same site (Sta. M533) during the experiment had the same order of magnitude as for the foraminifera in the unfed sediment cores.

Three days after feeding, there was a remarkable increase $(88.7 \%)$ in the organic carbon content of Cribrostomoides subglobosum (Fig. 1B). As the method cannot differentiate between the carbon content of the food ingested by the foraminifera and the plasma carbon, this value is not equivalent to an increase in biomass. The ultrastructural observations revealed the food was converted into foraminiferal biomass in the following days. This was documented by an increase of $16.9 \%$ in mean individual biomass ten days after feeding. In comparison, the unfed individuals had a growth increase of $8.7 \%$ compared to the initial situation. Some of the response might have resulted from minor artificial influences, such as the activation of nutrients from deeper sediment layers and a microbial reaction to the sampling and incubation procedure (Altenbach, 1992). This is consistent with an increase of the enzymatic decomposition of organic material in the unfed sediment cores, measured by the activity of hydrolytic enzymes (Köster and others, 1991).

The ATP content of fed Cribrostomoides subglobosum showed the same tendency as the organic carbon content during the experiment, with a distinct increase on the third day after adding the food (Fig. 2A). The unfed foraminifera maintained a low ATP level without large fluctuations between values in the time series. The ATP content of foraminifera selected from sediment cores taken from the collection site (M533) was the same as for the fed foraminifera in the experiment. In contrast to the ATP and ADP content of C. subglobosum (Fig. 2B), a strong decrease in AMP occurred one day after the feeding (Fig. 2C). This decrease coincided with an increase in ADP and ATP, suggesting a conversion from the AMP pool. Three days after feeding, the AMP content of the fed foraminifera increased again, reaching its original level. Six days after feeding, ADP and ATP contents were similar to those of the unfed foraminifera. The unfed individuals did not show this stabilization in AMP. Instead, their AMP levels dropped to very low values on the third day, but they recovered at the end of the experiment.

The adenosine nucleotide pool represents the physiological state of the cell and is a regulation mechanism itself; i.e., in a cell with a high ATP content, ATP-consuming processes are supported, whereas in a cell with a high AMP level, ATP-generating processes are supported and/or ATPconsuming processes are slowed down (Witzel, 1979; Graf and Linke, 1992). Both effects should be useful during periods of low food supply and starvation, at least as long as the organisms can survive and the ATP pool can be reestablished.

\section{$\leftarrow$}

shipboard microcosms was August 19, 1988, day -4 on the time axis. A food pulse of $1.1 \mathrm{~g} \mathrm{C} \mathrm{m}^{-2}$ was added 4 days later (day 0 ) to simulate a flux event. Note the different scales on $y$-axes. 

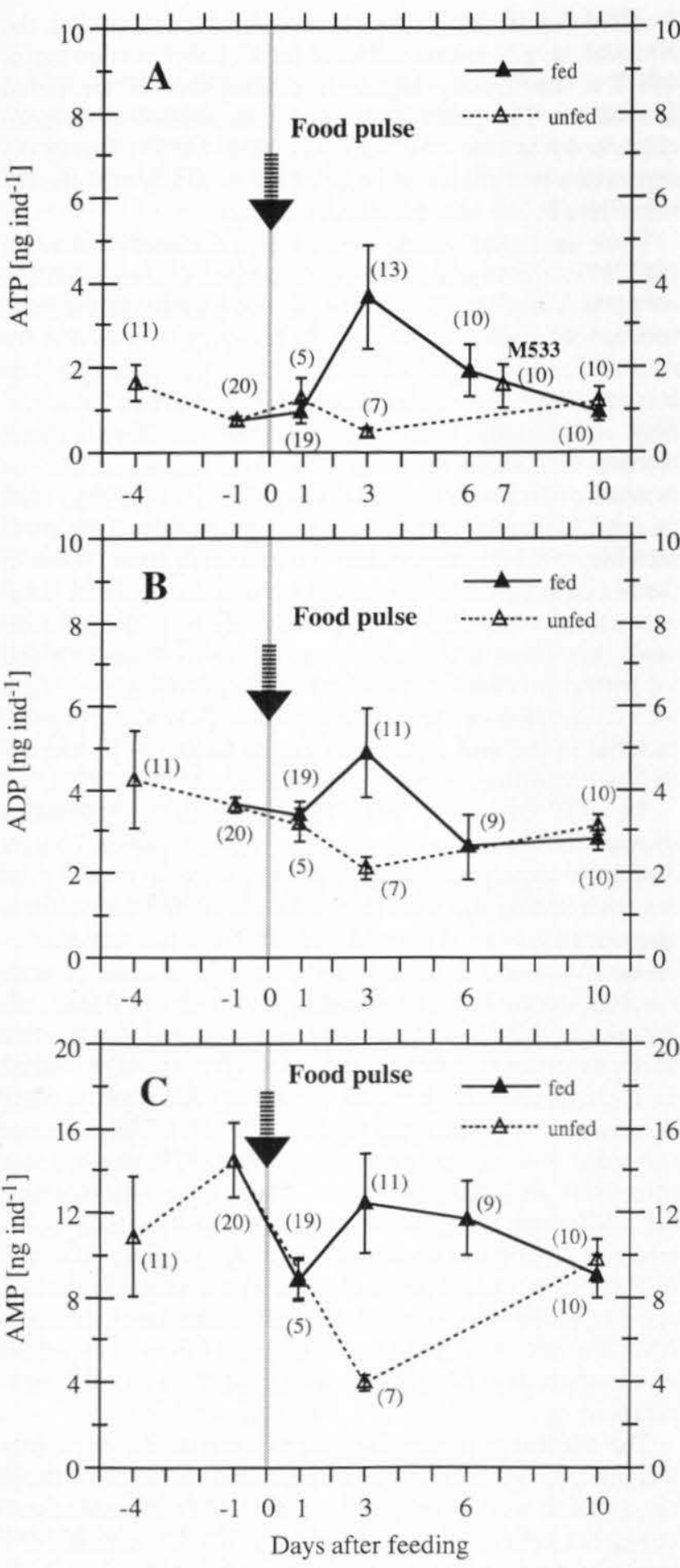

FIGURE 2. Development of the adenosine nucleotide contents of Cribrostomoides subglobosum during the experiment. Values in brackets indicate the number of individuals per measurement and bars the standard deviation. A. Adenosine triphosphate (ATP). During the feeding experiment, the same site from which the sediment cores for the experiment had been taken was sampled again (Sta. M533) to get ATP control values under natural conditions. B. Adenosine diphosphate (ADP). C. Adenosine monophosphate (AMP). Note the different scales on $\mathrm{y}$-axis.
The high AMP level as well as the dramatic fluctuations in the AMP content point out a key role of AMP in the nucleotide metabolism of Cribrostomoides subglobosum (Graf and Linke, 1992). In the feeding experiment, a distinct decrease in the AMP contents of fed and unfed foraminifera was found. This indicates a deactivation of the AMP blockade, a physiological "awakening" reaction. The reasons for the "awakening" could be the disruption during sampling and the vibrations of the ship. In the case of the unfed foraminifera, the "awakening" reaction led to a massive breakdown in the AMP pool; a physiological "awakening" reaction happened, but there was not enough food. The fed foraminifera regenerated their high AMP content only 3 days after the feeding. The experiment with $C$. subglooosum indicates that the first physiological response is merely a phosphorylation of AMP. This "awakening" reaction is possible without new production of purines, which would be an energetically expensive process. If the food is sufficient the foraminifera can start to produce biomass and increase ATP. On the other hand, it seems reasonable that the high AMP pool of the fed foraminifera might serve as a basis for further decomposition of the AMP molecule. This would lead to a production of purines, which might serve as nuclear material for reproduction. In the TEM investigations of the feeding experiment, however, no signs for reproduction in the foraminiferal community were found.

Nevertheless, the DNA concentrations in the sediment surface $(0-1 \mathrm{~cm})$ of the fed cores increased by $24 \%$ and $32 \%$ from day -4 to day 1 and 3 respectively, whereas there was no significant change in the unfed control (Fig. 1C). In the fed cores on day 6 , the former DNA concentrations of $29 \mu \mathrm{g} \mathrm{cm}^{-3}$ were re-established. In the control cores, DNA concentrations decreased from day 3 to day 10 by $25 \%$. Unfortunately there was no control measured on day 6.

\section{Timescale and Proportion of Response}

Looking at the timescale of the reaction to the food pulse, the foraminifera showed a distinct reaction in food uptake and increase in potential oxygen consumption only one day after feeding. The potential oxygen consumption values of fed and unfed Cribrostomoides subglobosum showed the same time-course development as the values of the sediment oxygen demand (SOD) during the experiment (Graf, oral communication, 1993). These oxygen consumption data can be converted to carbon respiration assuming a respiratory quotient of 1 (Graf, 1987). By integrating these data over 11 days (day 0 until day 10 of the experiment), a mean SOD of $68.8 \mathrm{mg} \mathrm{C} \mathrm{m}^{-2} \mathrm{~d}^{-1}$ can be calculated. As $C$. subglobosum had an average population density of 16,500 ind. $\mathrm{m}^{-2}$ in the topmost centimeter of the cores (Altenbach, 1992), the contribution of this species alone to the respiration of the total sediment community was up to $1.8 \%$ for the fed and $1.1 \%$ for the unfed $C$. subglobosum, respectively. Prior to feeding, C. subglobosum accounted for less than $0.2 \%$ of the sediment community respiration. As the ETS method measures only the potential oxygen consumption, this means that in both cases the enzymes of the electron transport chains were rapidly reactivated.

No matter how much significance is given to artificial effects during the microcosm experiment, the foraminifera 
consumed large amounts of particulate organic matter in response to the food pulse. In addition, 3 days after feeding, there was a remarkable increase in organic carbon, ATP and ADP content of this species.

An estimate of carbon turnover by foraminifera is given by Altenbach (1992). An increase of $1.73 \mu \mathrm{g}$ from the first to the third day after feeding was noted. Given an average population density of 16,500 specimens $\mathrm{m}^{-2}$, a consumption of $28.5 \mathrm{mg} \mathrm{C} \mathrm{m}^{-2}$ is obtained for this species. This consumption corresponds to $2.6 \%$ of the added food $(1.1 \mathrm{~g} \mathrm{C}$ $\left.\mathrm{m}^{-2}\right)$, whereas $19 \%\left(5.4 \mathrm{mg} \mathrm{C} \mathrm{m}^{-2}\right)$ of this incorporated carbon was converted to cytoplasmic bodymass. In comparison, only $0.1 \%$ of the organic carbon added was incorporated in microbial biomass (Köster and others, 1991). This highlights that the availability of food is a key factor in the ability of each member of the benthic community to react to a food pulse reaching the sea floor. Whereas the foraminifera observed in this experiment ingested a variety of particulate organic matter, microbial degradation of particles requires their colonization by bacteria. Since a substantial fraction of the extracellular enzymes are bound to the cell membranes or other surfaces (Boetius and Lochte, 1994), the bacteria have to dissolve particulate matter by mobilizing exoenzymes prior to incorporation. The supply of organic material in our experiment led to a stimulation of microbial decomposition (as measured by the activity of hydrolytic enzymes) with maximum enzymatic activity on the third day after feeding (Köster and others, 1991). With a time lag of approximately 6 days after feeding, the hydrolysis products were incorporated in microbial biomass (Köster and others, 1991). However, an increase of the bacterial biomass obtained from direct counts was not observed. One of the explanations for this discrepancy is the direct counting method itself, which is not sensitive enough for this grade of population fluctuation, whereas the DNA analysis of the entire sediment yielded an increase of 24 to $32 \%$. Another explanation is that the bacteria themselves became a food source for the other participants of the feeding experiment.

As the agglutinated foraminifer Cribrostomoides subglobosum accounts for only $25.3 \%$ of all living foraminifera in the size class greater than $250 \mu \mathrm{m}$, the total consumption and respiration of all species of benthic foraminifera in all size classes must be much higher. At our station on the Vøring Plateau, C. subglobosum is very abundant (up to 24,850 Rose Bengal stained individuals $\mathrm{m}^{-2}$ in the size class greater than $250 \mu \mathrm{m}$; Thies, 1991) and is also important in terms of biomass. It comprises up to $75 \mathrm{mg} \mathrm{C} \mathrm{m}^{-2}$ (Linke, 1989), much more than the nematode biomass of $7 \mathrm{mg} \mathrm{C}$ $\mathrm{m}^{-2}$ (Jensen, 1988). For comparison, Romero-Wetzel and Gerlach (1991) calculated the biomass (wet weight) of the total macrofauna from 17 box corer samples collected on the Vøring Plateau to be in the range of $10 \mathrm{~g} \mathrm{~m}^{-2}$. This, according to Steele (1974), is roughly equivalent to $1 \mathrm{~g} \mathrm{C}$ $\mathrm{m}^{-2}$. Based on these estimates, the foraminifer $C$. subglobosum contributes $7.5 \%$ to the biomass of the total community. Thus, foraminifera have to be considered as important members of the benthic community and as rapid and significant consumers of flux events in the Norwegian Sea.

\section{SUMMARY AND CONCLUSION}

Summarizing all the measurements gives a picture of benthic foraminiferal adaptations within the trophic system of the deep-sea community. The foraminiferal biomass is high, exceeding by far the meiofaunal biomass and running into ranges detected in benthic macrofauna. However, foraminiferal respiration is comparably low with respect to total benthic oxygen consumption when food is rare. Energy intensive activities are delayed by high AMP levels, but this AMP can be used quickly as an energy reservoir by conversion to ATP. After the food pulse, ETS activity increases roughly threefold. It takes about three days until the ETS activity and the lowered AMP pools reach their original levels. This time span coincides with maximum accumulation of organic matter in foraminiferal food vacuoles, the development of maximum enzymatic (microbial) activity in the sediment, and total benthic oxygen consumption. Biochemical activation, the "awakening" reaction to the food pulse, occurs at the onset of this time span. Conversion of ADP and ATP from the AMP pool determines energy investments for the formation of new biomass and possibly nuclear matter by subsequent purine production for reproduction. Thus, the alternation of the adenosine nucleotide pool and the total DNA level continues several more days. The awakening reaction also took place in the unfed samples, presumably as an artifact of the sampling procedure. Growth potential is detectable based on sources provided from the environment sampled. But, in contrast to individuals supplied with an additional pulse of organic matter, the dropping AMP levels in activated but unfed individuals recovered only slowly. The increase in biomass is smaller, and finally leads to a loss in total DNA.

Ongoing biological research focuses on foraminifera as a potential monitor of deep-sea food chains. Research benefits from high numbers of individuals in a broad range of marine environments. Foraminifera make up a major part of the benthic community, and specimens within their test are easily detected and handled. These advantages make foraminifera one of the most important groups in micropaleontology. Moving away from static concepts, such as physical or chemical properties of the bottom waters, the results discussed here give insight into dynamical adaptations of benthic foraminifera to alternating nourishment conditions in the deep sea.

It is important to note that the interpretation of faunal shifts in deep-sea assemblages has been traditionally guided by concepts developed from shallow-water environments. Both the pronounced annual changes in water properties and supply of plant-produced organic matter seen in the shallow ocean do not provide appropriate concepts for the deep sea. Over the last decade an increasing body of evidence has accumulated indicating that much, perhaps most, of the deep-sea floor is an environment of substantial temporal variability. This variability is driven largely by seasonal changes of processes occurring in surface waters (e.g., Billett and others, 1983; Rice and others, 1986; Tyler, 1988; Thiel and others, 1988/89; Smith and others, 1994; Graf and others, 1995). Although some recent studies (Sayles and others, 1994) contrast sharply with these previous reports, there is strong evidence that with increasing water depth, 
trophic conditions depend on the ability to react to short pulses of organic matter. In this environment benthic foraminifera are very well adapted and account for a significant part of the entire community turnover.

\section{ACKNOWLEDGMENTS}

We wish to thank the captain and crew of the R.V. Meteor and gratefully acknowledge the technical support of Annette Scheltz, Barbara von Brevern, Eric Steen and Wolfgang Queisser. The authors are grateful to P. Loubere and the anonymous reviewer for reading and helping to improve the manuscript. This is publication no. 230 of the Joint Research Program at Kiel University (Sonderforschungsbereich 313) supported by the Deutsche Forschungsgemeinschaft (DFG).

\section{REFERENCES}

AltenBACH, A. V., 1987, The measurement of organic carbon in Foraminifera: Journal of Foraminiferal Research, v. 17, p. 106-109. , 1992, Short term processes and patterns in the foraminiferal response to organic flux rates, in Jorissen, F. J., and Zachariasse, W. J. (eds.), Approaches to Paleoproductivity Reconstructions: Marine Micropaleontology, v. 19, p. 119-129.

Barnett, P., WatSon, J., and CONElly, D., 1984, A multiple corer for taking virtually undisturbed samples from shelf bathyal and abyssal sediments: Oceanologica Acta, v. 7, p. 399-408.

BathmanN, U. V., NoJ,. T. T., and v. Bodungen, B., 1991, Sedimentation of pteropods in the Norwegian Sea in autumn: DeepSea Research, v. 38, p. $1341-1360$.

-, Peinert, R., NoJ, T. T., and v. Bodungen, B., 1990, Pelagic origin and fate of sedimenting particles in the Norwegian Sea: Progress in Oceanography, v. 24, p. 117-125.

Billett, D. S., Lampitt, R. S., Rice, A. L., and Mantoura, R. F., 1983, Seasonal sedimentation of phytoplankton to the deep-sea benthos: Nature, v. 302 , p. $520-522$.

BoEtius, A., and LoCHTE, K., 1994, Regulation of microbial enzymatic degradation of organic matter in deep-sea sediments: Marine Ecology Progress Series, v. 104, p. 299-307.

Campos-Creasey, L. S., Tyler, P. A., Gage, J. D., and John, A. W., 1994, Evidence for coupling the vertical flux of phytodetritus to the diet and seasonal life history of the deep-sea echinoid Echinus affinis: Deep-Sea Research, v. 41, p. 369-388.

GRAF, G., 1987, Benthic energy flow during a simulated autumn bloom sedimentation: Marine Ecology Progress Series, v. 39, p. 23-29. , 1989, Benthic-pelagic coupling in a deep-sea benthic community: Nature, v. 341, p. $437-439$.

-, Bengtsson, W., Diesner, U., and Theede, H., 1982, Benthic response to sedimentation of a spring phytoplankton bloom: process and budget: Marine Biology, v. 67, p. 201-208.

, Gerlach, S. A., Linke, P., Queisser, W., Ritzrau, W. SCHeltZ, A., ThOMSEN, L., and WrTte, U., 1995, Benthic-pelagic coupling in the Greenland-Norwegian Sea and its effect on the geological record: Geologische Rundschau, v. 84, p. 49-58.

, and LINKE, P., 1992, Adenosine nucleotides as indicators of deep-sea benthic metabolism, in Rowe, G. T., and Pariente, V. (eds.), Deep-sea Food Chains and the Global Carbon Cycle: NATO ASI Series, v. C360, Kluwer Academic Publishers, Dordrecht, The Netherlands, p. 237-243.

GoODAY, A. J., 1988, A benthic foraminiferal response to the deposition of phytodetritus in the deep-sea: Nature, v. 332, p. 70-73. , and LAMBSHEAD, P. J., 1989, Influence of seasonally deposited phytodetritus on benthic foraminiferal populations in the bathyal northeast Atlantic: the species response: Marine Ecology Progress Series, v. 58, p. 53-67.

, and TURLEY, C. M., 1990, Responses by benthic organisms to inputs of organic material to the ocean floor: a review: Philosophical Transactions of the Royal Society London, v. A 331, p. $119-138$.

Hausmann, K., 1985, Protozoologie: Thieme Verlag, Stuttgart, p. 1351.
HEEGER, T., 1990, Elektronenmikroskopische Untersuchungen zur Ernährungsbiologie benthischer Foraminiferen: Berichte aus dem Sonderforschungsbereich 313 , Universität Kiel, v. 21, p. 1-139.

Hirschleber, H., Theilen, F., Balzer, W., v. Bodungen, B., and THIEDE, J., 1988, Forschungsschiff Meteor, Reise 7 vom 1. Juni bis 28. September 1988: Berichte aus dem Sonderforschungsbereich 313, Universität Kiel, v. 10, p. 1-358.

JENSEN, P., 1988, Nematode assemblages in the deep-sea benthos of the Norwegian Sea: Deep-Sea Research, v. 35, p. 1173-1184.

KAPUSCINSKI, J., and SKOCZYLAST, B., 1977, Simple and rapid fluorometric method for DNA microassay: Analytical Biochemistry, v. 83 , p. $252-257$.

Köter, M., Charfreitag, O., and Meyer-Reil, L.-A., 1991. A vailability of nutrients to a deep-sea benthic community: results from a ship-board experiment: Kieler Meeresforschung, v. 8, p. 127 133.

LINKE, P., 1989, Lebendbeobachtungen und Untersuchungen des Energiestoffwechsels benthischer Foraminiferen aus dem Europäischen Nordmeer: Berichte aus dem Sonderforschungsbereich 313, I/ niversität Kiel, v. 18, p. 1-123.

- 1992, Metabolic adaptations of deep-sea benthic foraminifera to seasonally varying food input: Marine Ecology Progress Series, v. 81 , p. $51-63$.

$\longrightarrow$, and LUTZE, G. F., 1993, Microhabitat preferences of benthic foraminifera - a static concept or a dynamic adaptation to optimize food acquisition? in Langer, M. R. (ed.), Foraminiferal Microhabitats: Marine Micropaleontology, v. 20, p. 215-234.

MEYER-ReIL, L.-A., and KösTER, M., 1992, Microbial life in pelagic sediments: the impact of environmental parameters on enzymatic degradation of organic material: Marine Ecology Progress Series, v. 81, p. $65-72$.

PfanNKuCHE, O., 1993, Benthic response to the sedimentation of particulate organic matter at the BIOTRANS station, $47^{\circ} \mathrm{N}, 20^{\circ} \mathrm{W}$ : Deep-Sea Research, v. 40, p. 135-150.

Rice, A. L., BILlett, D. S., FrY, J., JOHN, A. W., LAMPITT, R. S., Mantoura, R. F, and Morris, R. J., 1986, Seasonal deposition of phytodetritus to the deep-sea floor: Proceedings of the Royal Society of Edinburgh, v. 88B, p. 265-279.

ROMERO-WETZEL, M. B., and Gerlach, S. A., 1991, Abundance, biomass, size-distribution and bioturbation potential of deep-sea macrozoobenthos on the Vøring Plateau (1200-1500 m, Norwegian Sea): Meeresforschung, v. 33, p. 247-265.

Rowe, G. T., and PARIENTE, V., 1992, Deep-sea food chains and the global carbon cycle: NATO ASI Series, v. 360, Kluwer Academic Publishers, Dordrecht, 400 p.

SAYles, F. L., Martin, W. R., and Deuser, W. G., 1994, Response of benthic oxygen demand to particulate organic carbon supply in the deep sea near Bermuda: Nature, v. 371, p. 686-689.

Smith, K. L., JR., KaufmanN, R. S., and BaLdwin, R. J., 1994, Coupling of near-bottom pelagic and benthic processes at abyssal depths in the eastern North Pacific Ocean: Limnology and Oceanography, v. $39,1101-1118$.

STEele, J. H., 1974, The structure of marine ecosystems, Harvard University Press, Cambridge, 128 p.

Thiel, H., Pfannkuche, O., Schriever, G., Lochte, K., Gooday, A. J., Hemleben, Ch., Mantoura, R. F., Turley, C. M., PAtching, J. W., and RIEMANN, F., 1988/89, Phytodetritus on the deep-sea floor in a central oceanic region of the Northeast Atlantic: Biological Oceanography, v. 6, p. 203-239.

THIES, A., 1991, Die Benthos-Foraminiferen im Europäischen Nordmeer: Berichte aus dem Sonderforschungsbereich 313, Universität Kiel, v. 31, p. 1-97.

TURLEY, C. M., and LOCHTE, K., 1990, Microbial response to the input of fresh detritus to the deep-sea bed: Palaeogeography, Palaeoclimatology, Palaeoecology, v. 89 , p. 3-23

- GoOdAY, A. J., and Green, J. C., 1993, Maintenance of abyssal benthic foraminifera under high pressure and low temperature: some preliminary results: Deep-Sea Research, v. 40, p. 643-652.

TYLER, P. A., 1988, Seasonality in the deep sea: Oceanography and Marine Biology: An Annual Review, v. 26, p. 227-258.

WITZEL, K.-P., 1979, The adenylate energy charge as a measure of microbial activities in aquatic habitats: Archiv für Hydrobiologie Beiheft Ergebnisse Limnologie, v. 12, p. 146-165. 